\title{
Hvad jeg i fremtiden vil huske at værdsætte ved on-site undervisning
}

Katrine Lindvig ${ }^{1}$, Institut for Naturfagenes Didaktik, Københavns Universitet

Nu hvor jeg sidder og skriver dette bidrag til vores DUT Tidskapsel, er der egentlig ikke særligt meget fra 2020, jeg har lyst til at gemme. Det har på alle mulige måder været et hæsligt år, og ja-hatten har været alt for lille til mit eksploderende hoved. Jeg både misunder og irriteres over dem, der har haft evnen og overskuddet til at beholde den på, og jeg har mange gange ønsket at være en anelse mere introvert, så jeg også kunne shine i isolation. Der er intet i mig, der har shinet under nedlukningen. Jeg har været en grim blanding af bekymret, frustreret, presset og mest af alt - bitter. Og selvom jeg i min forskning har fokus på, hvordan man styrker brugen af digitale metoder i undervisningen, så har onlineundervisningen ikke fået det gode frem i mig. Når det så er sagt, så kan et bidrag til en tidskapsel måske også være en huskeliste til fremtiden om noget af det, vi fremover skal sætte pris på, værdsætte og lægge mærke til. Noget af det, som indtil marts 2020 var en ganske selvfølgelig og umærkelig del af det at undervise, men som overhoved ikke er selvfølgeligt længere. Her er min liste:

Når on-site undervisning igen er mulig, så husk at værdsætte:

\section{Pauserne}

Det kan godt være, at småkagerne er kedelige og mængden af kaffe tager overhånd, men de pauser er så vigtige. Det er monitorlyden på vores undervisning. Det er der, vi finder ud af, om noget skal forklares yderligere, om grupperne skal have mere tid til at arbejde, om vi har for mange slides eller taler for hurtigt. Det er der, vi finder ud af, om ham bagerst i lokalet er koblet af, uinteresseret eller blot lidt til den stille side. De pauser er guld værd. Man kan godt holde pause i Zoom, men det er ikke det samme, og vi gør det for det meste alene.

\section{Muligheden for at aflæse kropssprog og synkronisere}

Forskning viser, at vi inden for de allerførste minutter, vi mødes, synkroniserer kropssprog, lige fra positur til størrelse af pupiller. De første minutter er afgørende for, at vi føler os set og inkluderet i fællesskabet. Det er (endnu) ikke muligt online, idet de få sekunders forsinkelse i forbindelsen afkobler synkroniseringen og i mange tilfælde gør, at vi i stedet for at føle os set, bliver misforstået eller misfortolket.

\section{Ikke at skulle undervise foran et spejl}

Man kan nøjes med at kigge på sine kursister, sin medunderviser, på uret og på sine slides. Man behøver ikke at forholde sig til alle mulige fancy baggrunde eller din egen frisure efter 6 timer med headset. Det er virkelig

${ }^{1}$ Kontakt: katrine.lindvig@ind.ku.dk 
noget at glæde sig over.

\section{Løbende justering af undervisningen}

Den første og eneste gang jeg underviste on site efter nedlukningen, lignede jeg en biavler, der var gået forkert. Fordi jeg og min medunderviser begge bar visir, blev det ekstremt tydeligt, hvor meget vi planlægger og justerer undervejs. Jeg har ikke tal på de gange, vi stødte visirerne sammen, når vi forsøgte at justere programmet eller give en besked. Muligheden for at kalibrere og tilpasse sin undervisning er meget svær i onlineundervisning, hvor rammerne skal være ekstremt tydelige for deltagerne. Spontanitet har trange kår i et Zoom-rum med 25 deltagere, og smalltalk er bare bedre IRL. Selv hvis det foregår gennem et visir.

\section{Betingelser for brug af denne artikel}

Denne artikel er omfattet af ophavsretsloven, og der må citeres fra den.

Følgende betingelser skal dog være opfyldt:

- Citatet skal være i overensstemmelse med "god skik"

- Der må kun citeres „i det omfang, som betinges af formålet"

- Ophavsmanden til teksten skal krediteres, og kilden skal angives ift. ovenstående bibliografiske oplysninger

(C) Copyright

DUT og artiklens forfatter
Udgivet af Dansk Universitetspædagogisk Netværk 